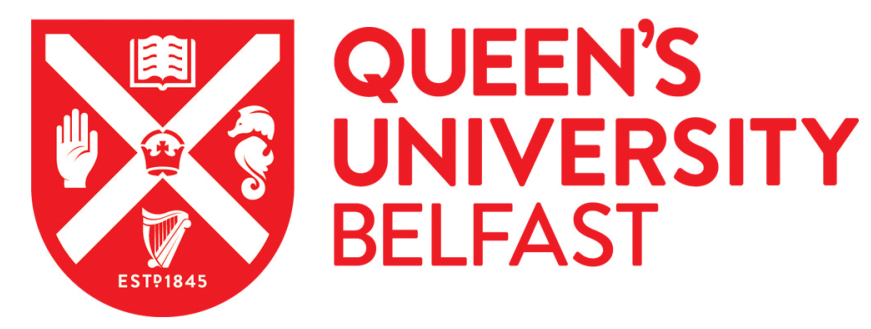

\title{
Neoliberal Place Competition and Culturephilia: Explored Through the Lens of Derry Londonderry
}

Boland, P., Murtagh, B., \& Shirlow, P. (2020). Neoliberal Place Competition and Culturephilia: Explored Through the Lens of Derry Londonderry. Social and Cultural Geography, 21(6), 788-809.

https://doi.org/10.1080/14649365.2018.1514649

Published in:

Social and Cultural Geography

Document Version:

Peer reviewed version

Queen's University Belfast - Research Portal:

Link to publication record in Queen's University Belfast Research Portal

Publisher rights

Copyright 2018 Taylor and Francis. This work is made available online in accordance with the publisher's policies. Please refer to any applicable terms of use of the publisher.

\section{General rights}

Copyright for the publications made accessible via the Queen's University Belfast Research Portal is retained by the author(s) and / or other copyright owners and it is a condition of accessing these publications that users recognise and abide by the legal requirements associated with these rights.

Take down policy

The Research Portal is Queen's institutional repository that provides access to Queen's research output. Every effort has been made to ensure that content in the Research Portal does not infringe any person's rights, or applicable UK laws. If you discover content in the Research Portal that you believe breaches copyright or violates any law, please contact openaccess@qub.ac.uk. 


\section{Neoliberal Place Competition and Culturephilia: Explored Through the Lens of Derry Londonderry}

\section{Introduction}

In recent years an interesting international debate has focused on the impact and legacy of major cultural events. According to Garcia (2017, p. 3195) a "belief in the power of cultural interventions as catalysts for broader urban change is widespread and dominates policy discourse across the globe". In this article we contribute to these deliberations through an examination of Derry Londonderry $(\mathrm{D} \sim \mathrm{L})^{1}$ as the UK's first ever City of Culture (CoC) in 2013. This was the then Labour Government's flagship cultural policy and so attracted a huge amount of international and national media attention and significant local interest (Boland, Murtagh \& Shirlow, 2016; Murtagh, Boland \& Shirlow 2017; Doak, 2014, 2018). In framing the paper we draw upon the theoretical scaffold of neoliberal urbanism; in augmentation, we present our own conceptual contribution in applying culturephilia ${ }^{2}$, impact inflation and the three $C s$ to the analysis of $\mathrm{D} \sim \mathrm{L}$. Our central argument is that neoliberal urbanism generates fierce inter-city competition to host major cultural events. Moreover, this process conditions the actions of local stakeholders when producing bid documents to the judging panels and results in extravagant and excessive economic targets for impact and legacy, i.e. impact inflation. For us, this is part of a wider fetishisation of the alleged curing qualities of culture, or culturephilia, which is underpinned by claims that cultural and creative policy interventions can enhance cities' performativity on competitiveness, what we term as the three Cs of local and regional development. The structure of the paper is as follow. Next we explain and justify the research methodology; that is followed by a discussion of the theoretical framework that underpins the paper; the subsequent section comprises a theoretically-informed empirical analysis of $\mathrm{D} \sim \mathrm{L} U K \mathrm{CoC}$; the paper ends with a reflection of the research findings and consideration of the contribution to knowledge.

\section{Research Approach}

In this paper we draw upon the fieldwork from a three year research project ${ }^{3}$. The first point to make is that at the time of the designation of UK CoC on $15^{\text {th }}$ June $2010 \mathrm{D} \sim \mathrm{L}$ was a city busily coping with the fallout from the trauma of 'the Troubles' (violence associated with a society deeply divided between Catholic-Nationalists and Protestant-Unionists; more on this later). In terms of the conduct of research

\footnotetext{
${ }^{1}$ Catholic-Nationalists refer to the city as Derry to reflect their Irishness while elements within Protestantism-Unionism use Londonderry to capture their Britishness.

${ }^{2}$ This concept draws on the use of 'metrophilia' to describe an intellectual, policy and political climate characterised by an overwhelming 'pro-urban bias' (Morgan, 2014).

${ }^{3}$ Full details to be provided after peer review.
} 
this made D L a quite different prospect compared to previous UK-based European Capitals of Culture ${ }^{4}$ in Glasgow 1990 and Liverpool 2008. Given this uniquely contentious environment our research required respect and sensitivity in terms of how we interrogated culture in a culturally divided city. In response to this we devised a research strategy to access information and knowledge concerning the impact and legacy of CoC prior to, during and post 2013. More specifically, our analytical approach adopts an interpretivist epistemology (Bryman 2012; Hay 2011) in terms of seeking out as many divergent voices as possible, and then triangulating the different experiences and interpretations of those involved in and affected by CoC.

Between September 2013 and October 2016 we conducted 55 semi-structured interviews with elite stakeholders, third sector agencies, tourist operators, cultural, community and voluntary organisations, arts groups, cultural performers, artists and educationalists. We conducted four focus groups with residents (ranging between 10 and 14 in number, and 18-70 in age) in two working class Catholic and Protestant areas. This paper builds upon issues that emerged from this fieldwork and our previous publications (Boland, Murtagh \& Shirlow, 2016; Boland, Mullan \& Murtagh, 2018; Murtagh, Boland \& Shirlow 2017): cross-community relations; economy and jobs; image and tourism; and most importantly impact and legacy. In so doing we focus on respondents directly involved in designing and delivering $\mathrm{CoC}$ and those responsible for producing the bid document and legacy plans. Derry City Council ${ }^{5}$, Culture Company ${ }^{6}$, Ilex Urban Regeneration Company ${ }^{7}$ and senior local politicians played strategically important roles so their views are given priority in relation to the processes leading up to the bid application, the aspirations for 2013 and ambitions for impact and legacy post 2013. This enables us to analyse the factors that influenced the thinking of civic leaders, and construction of the documentation accompanying CoC. We also engage with non-elite stakeholders, whose views are often unheard in official renditions of impact and legacy, as a counterpoint to the interpretations of elite stakeholders. The qualitative fieldwork was supplemented by secondary sources. This involves a detailed desk study of the bidding guidance for CoC and D L's bid document, legacy plans and end of term evaluation. This is important in examining the content of the UK Government's guidelines, and how this shaped the objectives for the city and its legacy targets. Collectively, the findings generate a rich tapestry of interpretations concerning the impact and legacy of $\mathrm{CoC}$ in $\mathrm{D} \sim \mathrm{L}$.

\footnotetext{
${ }^{4}$ Funded by the European Commission to the sum of 1.5 million Euros. During this annual event host cities develop their cultural infrastructure, showcase their cultural talents and attract cultural tourists. It is designed to enhance the 'development of cities', raise their 'international profile', celebrate the 'richness and diversity' of cultures in Europe and link local culture to a 'common European cultural identity' (European Commission, 2014).

${ }^{5}$ Following local government reorganisation in 2015 it is now named Derry City and Strabane District Council.

${ }^{6}$ Culture Company was officially wound down on 31 ${ }^{\text {st }}$ March 2014.

${ }^{7}$ Ilex closed on 31 ${ }^{\text {st }}$ March 2016.
} 


\section{Theoretical Framework}

\section{Neoliberal urbanism and place competition}

In today's 'audit society' there is a 'near obsessive' focus on monitoring, evaluation and 'fetishism of targets' (Hall, 2011; Hesmondhalgh, Nisbett, Oakley \& Lee, 2015; Newsinger, 2015). This is particularly evident in international cultural policy debates that involve a "cultish obsession with the economy" (Belfiore, 2015, p. 106). An important point is that funding for various cultural initiatives is almost always conditional upon delivering socio-economic impact ${ }^{8}$ (Garnham, 2006; Markusen \& Gadwa, 2010; Miles, 2005; Nutley, Davies \& Walter, 2002; Taylor, 2006). Given this, there is a ubiquitous fixation with impact and legacy targets for major cultural policy interventions (Falk \& Hagsten, 2017; Garcia, 2017; Garcia \& Cox, 2013). However, Gibson and Stevenson (2004, p. 2) refer to the "distinction in policy rhetoric and actual outcome"; for Miles (2005, p. 975) "the expectation that they will produce sustained social and distributive economic benefits alone is arguably an unreasonable one"; McGuigan (2005, p. 229) talks of "an implausible palliative to exclusion and poverty"; while Belfiore (2006, 2009, 2015) is critical of the 'paltry evidence' legitimating 'exaggerated claims' regarding culture, and calls for 'sober realism' to avoid the dangers of 'bad economics' linked to cultural events.

A key question is why is this the case? Our position is that a robust explanation is to be found with reference to neoliberal urbanism. In particular, we focus our attention on the wider conditioning forces of neoliberal place competition and, in presenting our own theoretical advancement, the three Cs, impact inflation and culturephilia. Such an approach has ontological and epistemological value in capturing the economic realities, political pressures and material opportunities that shape the actions and articulations of local stakeholders responsible for designing and delivering a major cultural event.

Neoliberal theory provides the conceptual tools that inform the empirical analysis of this paper. There is a wide-ranging literature on neoliberalism or neoliberalisation as some prefer (e.g. Brenner \& Theodore, 2002; Brenner, Peck \& Theodore, 2012; Harvey, 2006; Jessop, 2002; Massey, 2014; Mayer \& Künkel, 2012; Peck \& Tickell, 2002, 2006; Peck, Brenner \& Theodore, 2009; Peck, Theodore \& Brenner 2010, 2013; Pinson \& Morel Journel, 2016). In the 1970s-80s neoliberalism emerged as a political-economic project writ large; its impetus was a right-wing intellectual and ideological reaction to Keynesian

\footnotetext{
${ }^{8}$ Belfiore $(2006,2015)$ offers a problematisation of the 'narrow focus' on economic impact, set against the merits of the wider 'multiple dimensions' of public value; while Garcia and Cox (2013) distinguish between aspirational impact and actual impact, and between impact during the cultural year and the long-term.
} 
economics and the crisis of global capitalism (Ampuja, 2015; Chun, 2017). For Peck and Tickell (2006, p. 28) neoliberalism represents a "distinctive political-economic philosophy....dedicated to the extension of market (and market-like) forms of governance, rule, and control across...all spheres of social life". Core neoliberal beliefs constitute an avowed faith in market rationality, deregulation, privatisation, individualism, competitiveness, entrepreneurialism and enterprise (Castree, 2010; Harvey, 2006; Peck, 2010; Peck \& Tickell, 2002, 2006). Based on this, it is often claimed that neoliberalism represents a return to the principles of the classical economists of the $19^{\text {th }}$ Century and $20^{\text {th }}$ Century thinkers such as Milton Friedman and Friedrich von Hayek. However, such a literal reading is highly questionable on matters such as Government interventionism, equilibrating market forces and concern for societal inequality (Le Gales, 2016; Lovering, 2007; Pinson \& Morel Journel, 2016; Storper, 2016).

For key commentators the current era is one where the political economy of neoliberal urbanism is hegemonic (Brenner \& Theodore, 2002; Jessop, 2002; Mayer \& Künkel, 2012; Peck et al., 2009, 2013). Over time advocates of neoliberal ideas came to populate positions of power in industry, media, commerce, institutions, politics and public policy at global, national, regional and local scales (Harvey, 2006; Peck \& Tickell, 2006). However, neoliberalism is not a uniform process as it plays out differently in different spatial settings, i.e. 'variegated geographies' (Brenner, Peck \& Theodore, 2010; Peck et al., 2009). Olesen (2013) notes that across Europe there have been different stages of 'roll-back', 'roll-out' and 'roll-with-it' neoliberalism (after Peck \& Tickell, 2002, 2006). Therefore, experts point to the 'process of neoliberalisation' to encapsulate how it is politically constructed and its place contingencies; described as 'actually existing neoliberalism' rather than a 'realisable condition' (Brenner, Peck \& Theodore, 2012; McGuirk, 2005; Peck, Theodore \& Brenner, 2010). Although the 2008 economic crash raised questions as to whether the neoliberal project was 'on the ropes' (Peck et al., 2010), it proved to be an 'adaptable regime' (Aalbers, 2013; Brenner et al., 2010, 2012). Jessop (2013) terms this 'crisis management' as 'rollforward neoliberalism'. Thus, there has been "no serious unsettling of neoliberal ideological hegemony" (Massey, 2014, p. 2034) as 'market fundamentalism' is extremely difficult to supplant (Mayer \& Künkel, 2012; Oosterlynck \& Gonzalez, 2013; Peck et al., 2013).

Others commentators question neoliberal theory (Chun, 2017; Featherstone, Strauss \& MacKinnon, 2015; Featherstone, 2015; Hall, 2011; Le Galès, 2016; Newman, 2014; Pinson \& Morel Journel, 2016; Storper, 2016; Watkins, 2010). It is labelled a 'chaotic concept' that 'lumps together' various issues, trends and practices; that not all socio-spatial change is caused by neoliberalism; that neoliberal policies are often anti- or illiberal as opposed to liberal. More specifically, Newman (2014) points to its conceptual 
'promiscuity', Watkins (2010) identifies 'imprecision and overuse', Hall (2011) is concerned about lapsing into 'reductivism', while Featherstone et al. (2015) argue that it engenders 'narrow debates'. Taken together, such unease leads to criticism that neoliberal theory exhibits an 'exaggerated hegemony' (Featherstone, 2015).

Rather than re-opening these extensive and well-trodden debates, we focus on one specific issue that has relevance to our argument. According to Harvey (2006, p. 145) neoliberalism has "swept across the world like a vast tidal wave of institutional reform and discursive adjustment". An important issue to emerge is the relative role of human agency within the dominant ideology of neoliberalism amid claims we have entered an era of 'post politics' (Beveridge \& Koch, 2017; Davidson \& Iveson, 2015; Dikeç \& Swyngedouw, 2017; Featherstone et al., 2015; Paddison, 2009; Swyngedouw, 2017). Speaking to human agency, Featherstone et al. (2015, p. 5) state: "Rather than positioning neo-liberalism as having thoroughly reworked common sense, it can focus on the ongoing struggles, the dissent and scepticism". On this, Dikeç and Swyngedouw (2017) accept that 'incipient insurgencies' of 'profound discontent' have politicised the 'urban landscape' as the excluded rise against the 'inegalitarian and embedded injustices' of neoliberalism. However, for them the trick is transformation from 'ordinary to extraordinary politics' and from 'outbursts of indignation' to 'sustained transformative strategies'.

In terms of our position we are influenced by Massey's (2014) take on this issue. For her neoliberalism extends beyond the economic to become cemented in our everyday thoughts and actions:

"Anyway, 'neoliberalism' here is about more than economics. It's also about the slow building of a new common sense - a hegemonic ideology - in this case of market relations, of competitive individualism, of private gain... [it] has altered our very senses of ourselves, invaded our imaginations, moulded our identities...its constituent ideas have become beyond question, natural" (Massey, 2014, pp. 2036-2037, our emphasis).

We are very sympathetic to Massey's reasoning. Our position is that neoliberalism significantly shapes our material and cognitive being to the extent that we (as citizens, workers, consumers) consent (consciously and unconsciously) to a neoliberal mode of thinking and behaving. Obviously we do not believe that neoliberalism inevitably reduces us to uncritically compliant automatons; however, we do suggest that neoliberal ways of thinking and behaving have become creatively but firmly institutionalised (educationally, economically, culturally, socially and politically) and are subtly naturalised in the mindset 
of the citizenry, particularly influential public servants such as economic development officers, spatial planners and elected politicians. We explore this is more detail in the following section.

Of importance to this paper is 'neoliberal', 'global', 'entrepreneurial' or 'competitive urbanism' (Dikeç \& Swyngedouw, 2017; Harvey, 1989; Keil, 2009; McGuirk, 2015; Swyngedouw, 2017) and the concomitant intensity of place ('territorial', 'inter-urban', 'shoulder-to-shoulder') competition between cities around the world (Castree, 2010; Peck et al., 2013; Pike, Rodríguez-Pose \& Tomaney, 2017; Sheppard et al., 2015). For Peck (2014, p. 398) "neoliberalised rules of the game have further upped the stakes in interurban competition". In these 'globalised place wars' inter-area rivalries involve aggressive contests for various forms of investment, labour, tourists, jobs, cultural and sporting events? ${ }^{9}$. He also refers to the "orthodoxy of competitive globalism - cities in a war of all against all, battling for winning positions under the yoke of globalizing disciplines" (Peck, 2015, p. 163). For Brenner and Schmid (2015, p. 153) this is evidenced in "the worldwide diffusion of place marketing campaigns"; a neoliberal competitive process that is widely regarded as planetary - part of what Paddison (2009) and MacLeod and Jones (2011) term 'mobile urbanism'. Indeed, Keil (2009, p. 232) claims that "the entire society, even nature must now be competitive". Connecting to our focus, Wilson and O’Brien (2012, p. 16) note that competitive titles such as ECoC and $\mathrm{UK} \mathrm{CoC} \mathrm{"bring} \mathrm{national} \mathrm{attention} \mathrm{and} \mathrm{exposure} \mathrm{that} \mathrm{would} \mathrm{be}$ otherwise difficult and expensive to secure, encourages a renewed focus and branding opportunities, and acts as an external marketing device".

Given this context, we point to "the disciplining and constraining effects of inter-urban competition" that "induce cities to behave entrepreneurially" (Peck, 2014, p. 398, our emphasis; also Paddison, 2009). As noted above we believe that neoliberal ideas have infected all aspects of our lives as they 'alter/command/invade/impact' our thoughts, consciousness and behaviour and how we think about, understand and interpret the world around us, in particular its political, economic, societal and cultural dimensions (Hall, 2011; Harvey, 2006; Massey, 2014; McGuigan, 2005). More specifically, there is a body of work showing that neoliberal ideas increasingly condition the thinking of city planners in Europe (Olesen, 2013, 2014; Sager, 2011, 2015, 2016) and specifically the UK (Allmendinger \& Haughton, 2009, 2010, 2013, 2015; Boland, 2014; Haughton, Allmendinger \& Oosterlynck, 2013). Here in Northern Ireland Boland (2014) refers to the 'uncritical acceptance' of neoliberal concepts in economic policy and spatial planning; instructively, a senior economic development officer in Belfast opined:

${ }^{9}$ Such as Florida's (2003) creative classes, European Capitals of Culture (Garcia and Cox, 2013) and Olympic Games (Gold and Gold, 2008). 
"There are no alternatives to competitiveness" (cited in Boland, 2014, p. 778). The pro-growth imperative instils a belief that place competition is omnipresent and unavoidable (perhaps even natural) and so must be engaged with and responded to. Moreover, in terms of our focus it conditions the types of actions and activities required to secure a major cultural event (i.e. they become omnipotent).

Let us consider ECoC with its global 'brand status' (Ashworth \& Kavaratzis, 2016; Richards \& Wilson, 2004; Tucker, 2008; Wilson \& O’Brien, 2012). In the 'place wars' (after Peck, 2014) to host this 'great accolade' city leaders compete on the content of their bid documents that are populated with ambitious economic outputs and social outcomes (Falk \& Hagsten, 2017; Garcia, 2017; Garcia \& Cox, 2013; Lähdesmäki; 2014; O’Callaghan, 2012). In her review of Glasgow 1990 and Liverpool 2008 Garcia (2017, p. 3188) reveals that "expectations of the ECoC as a catalyst for urban transformation had rocketed". Similarly, Falk and Hagsten (2017, p. 2176) argue "event planners often argue that hosting the ECoC leads to a long-term increase in tourism demand, and stimulates urban regeneration, city branding and economic development". It is important to state this occurs despite health warnings that we "should not set too high an expectation on boosting growth by means of events like the Cultural Capital" (Sjøholt, 1999, p. 346). Indeed, evidence points to negative consequences of $\mathrm{ECoC}$ concerning funding arrangements and programme management resulting in socio-spatial division, gentrification, class marginalisation, lack of jobs, counter-cultural movements etc. This is termed 'the politics of ECoC' that has generated 'tension, debate, objection' in host cities (Authors, 2016; Lähdesmäki 2013; Ooi et al., 2014). Useful examples include Cork (O'Callaghan 2012; O’Callaghan \& Linehan 2007), Glasgow (Mooney, 2004; Tretter, 2009), Liverpool (Boland, 2010, 2013; O’Brien, 2011), Turku (Lähdesmäki, 2013), Pécs (Németh, 2016) and Istanbul (Gunay, 2010).

Notwithstanding this it remains the case that ECoC is fiercely sought after and during the bidding process "participants cannot afford to opt for lesser or different visions and promises than those offered by their competitors" (Németh, 2015, p. 5). Moreover, "candidate cities are using enormous amounts of time and expenses to...prepare the city to win the title" (Lähdesmäki, 2014, p. 493). Competing cities, and judging panels, unofficially acknowledge the necessity to elevate the anticipated impact otherwise the bid will almost certainly fail. Revealingly, amongst those bidding to be UK CoC 2013 there was a distinct perception "that cities with the strongest infrastructure in place (for example with baseline visitor figures used to predict tourism growth) and the more systematic bid would be most likely to succeed" (Wilson \& O’Brien, 2012, p. 21). So in this beauty contest - chiefly amongst cities requiring urgent economic revitalisation - there is a conditioning effect in terms of the hyperbole centred on hosting the event; where glossy documents, slick presentation and ambitious legacy are essential (neoliberal) tools of the (place 
competition) trade. The stark reality is that to succeed cities must out-bid their rivals. So there is a realism about the necessity to exaggerate targets. For us, this impact inflation represents a conditioning effect of neoliberal 'place wars' and the need to secure a high profile cultural event for a needy local economy. For example, in terms of Peck's (2015) military analogy the armoury involved in 'a war of all against all' necessarily involves an uplift in expectations concerning culture, creativity and competitiveness.

\section{Three Cs, culture's curing qualities and culturephilia}

We identify three Cs of local and regional development as policies based on culture and creativity are deemed to enhance the competitiveness of local, regional and national economies (Belfiore, 2015; Colomb, 2011; Garnham, 2005; Landry \& Wood, 2003; Miles, 2005; Pratt, 2010, 2011). Evidence can be found in influential reports from the British Council (2012, 2014), UNESCO/UNDP (2013), Warwick Commission (2015) and World Cities Culture Forum (2013). UNESCO/UNDP (2013, p. 109) refer to the "importance of culture and creativity to ongoing economic development and global competitiveness". World Cities Culture Forum (2013) state that in the "wider debate about the economic competitiveness of cities, most such measures have included...culture's role in city life" (p. 19); it also notes the "critical contribution of culture to the economic and social success of cities" (p. 6). In terms of public policy this has led to "unprecedented visibility and prominence" of culture (Belfiore, 2006, p. 23), the "embedding of culture at the heart of day-to-day national government"10 (Pratt, 2014, p. 8) and a focus on cultivating the cultural economy and cultural/creative industries ${ }^{11}$ (Amin \& Thrift, 2007; Castree, 2004; Florida, 2003; Landry, 2006; Miller, 2008; Pratt, 2004). On this, the literature refers to claims that cultural policies and events can generate investment, jobs, tourism and image change for the city; given this, culture is perceived to be a significant 'economic resource' (Evans, 2001; Gray, 2006; Miles \& Paddison, 2005; Pratt, 2011; Stevenson, Rowe \& McKay, 2010). We term this the curing qualities of culture in tackling a range of seemingly intractable socio-economic problems; for example, a senior civil servant from Ilex claimed (in Heineken terminology): “Quite often culture can go in and address issues that other things can't, it reaches the parts others don't reach" (Interview, 2016). Other commentators refer to the 'dynamism of culture' (Pratt, 2014), 'lionization of culture' (McGuigan, 2009), 'transformative powers of culture'

\footnotetext{
10 This is most visibly demonstrated in the creation of a Government Department for Culture, Media and Sport (formerly Department for National Heritage) under New Labour in 1997. On a global stage, there are International Culture Summits, involving Culture Ministers and key cultural players, deliberating on the 'power, position and profile' of cultural industries and placing culture on the 'centre of political stage' (www.culturesummit.com).

11 There is a conceptual and policy 'messiness' surrounding the creativity discourse, and terminological issues regarding what industries constitute the cultural and creative sectors (see Pratt, 2014). We do not intend to rehearse these debates here, suffice to say there is evidence of conceptual and policy conflation. According to the Warwick Commission (2015, p. 12) during 2013 the UK cultural and creative industries grew by $9.9 \%$, employed 1.7 million people, contributed $f 77$ billion to the economy and represented $5 \%$ of the national economy.
} 
(Belfiore, 2015) and 'just add culture and stir' (Gibson \& Stevenson, 2004) narratives. Connecting to our theoretical discussion this "neoliberalisation of culture" ${ }^{12}$ (McGuigan, 2005) appears in the desire to 'economise/marketise/privatise' culture for 'instrumental economic ends' to achieve city competitiveness (Newsinger, 2015; also Gattinger \& Saint-Pierre, 2010), and a focus on the 'economic value' of the arts and culture rather than their 'public good' (Belfiore, 2015; O'Callaghan, 2012; Wilson \& O’Brien, 2012).

There has been an extension to the curing qualities of culture. Not only can culture (allegedly) tackle major geo-economic challenges such as unemployment and poverty, it is an antidote to geo-political problems including conflict and extremism (British Council, 2012, 2014; UNESCO/UNDP, 2013; World Cities Culture Forum, 2013). The British Council (2014, p. 10) claim "culture can play a positive role in supporting people emerging from conflict". There are two aspects: firstly, building trust, dialogue and shared understandings of difficult issues; secondly, post-conflict reconstruction and societal healing. Thus, culture is a resource leading to peace and reconciliation. According to UNESCO/UNDP (2013, p. 9) the "contribution of culture...results in inclusive social development, inclusive economic development...peace and security". Similarly, the British Council (2014, pp. 3-4, inset added) states:

"Culture can and should play a role in bringing people together, even those with very different world views. Culture can undoubtedly change individual lives...Culture is a force for dialogue, tolerance and social cohesion... [It] can play an important role in helping countries emerge and recover from periods of conflict".

In our view the three $C s$ are reified and concretised in the thinking of nation states and international cultural institutions. It is evidence of what Pratt (2014, p. 5) calls an ongoing "dramatic shift in meaning and practice" of culture. In terms of our theoretical advancement we argue that such wide ranging transformatory powers represent culturephilia - a disproportionate fondness of and undue faith in the curing qualities of culture. This does not mean we are entirely dismissive of culture. Rather, as we have demonstrated elsewhere culture can generate genuine transformative change, for example, in its role as a 'peace resource' (Boland, Murtagh \& Shirlow, 2016); however, its ability to deliver as an 'economic resource' in cities of culture remains under scrutiny (Falk \& Hagsten, 2017; Garcia \& Cox, 2013). In leading us into the empirical analysis, Wilson and O'Brien (2012, p. 7) reveal that "less attention has been

\footnotetext{
12 In the UK Hesmondhalgh et al. (2015) show that New Labour had a 'complex relationship' with neoliberalism as regards its cultural policies; moreover, over time using the term neoliberalism to describe different phases of public policy is somewhat 'simplistic'.
} 
paid...to the differing situated contexts, motivations and expectations that mobilise individual cities...to engage in culture-led regeneration strategies and practices".

\section{UK City of Culture}

Neoliberal 'place wars' and bidding guidance

In January 2009 then Secretary of State Andy Burnham announced the Department of Culture, Media and Sport (DCMS) was considering the introduction of a national cultural event. Six months later a working group ratified the proposal for UK CoC; an award focused on a particular city or area ${ }^{13}$ to be designated once every four years beginning in 2013. Although not accompanied by public funding CoC was the Labour Government's celebratory cultural initiative 'inspired' by and aiming to 'build on the success' of Liverpool's time as ECoC 2008 (DCMS, 2009, 2013, 2015). The generic objectives of CoC are to increase media interest in the host city, stimulate tourism, bring community members together, and facilitate professional artistic collaboration on creative projects. Moreover, it is claimed that:

"UK City of Culture is more than just a title. It's a focus, a rallying cry, a call to action, an opportunity to create and innovate, to build local pride, to show the world who you are and what you can do. It can inspire, instil a sense of ambition and provide the base for a real step change" (DCMS, 2013, p. 3).

We begin our analysis by considering the bidding guidance issued by DCMS. The first point to make, linking back to theory, is that $\mathrm{CoC}$ is very much a 'competition' between 'bidding areas' and a 'prize to be coveted' (DCMS, 2009, 2013), that is indicative of Peck's (2014) neoliberal 'place wars'. Reflecting ECoC, the thinking underpinning $\mathrm{CoC}$ is that culture can be a 'catalyst for change' and deliver important 'step changes' for the designated city. For applicants seeking to host CoC 2013 there were different stages to the process: an outline proposal, an initial bid, then a final bid. At the first stage applicants received detailed feedback from the Independent Advisory Panel and expert assessors on the 'strengths and weaknesses' of their documents (withdrawn for the 2017 competition). Applicants were also required to answer 'clarification questions' from expert assessors, those shortlisted were then asked to deliver verbal presentations on the merits of their bid. These written and oral contributions fed into the formal process of totting up scores on the 'assessment criteria' (DCMS, 2009, pp. 9-13, 2013, pp. 15-23). Interestingly, the bidding guidance urged applicants to display "credibility in their plans" and be "reasonable in what is

\footnotetext{
${ }^{13}$ There is no predetermined minimum size of population for the applicant area.
} 
expected"; in addition, "the assessment criteria relate to the content of bids, not their form of presentation" (DCMS, 2009, p. 2, p. 8). However, there is also a requirement to "create a demonstrable economic impact...maximising the legacy"; such that, bids must be "ambitious and stretching... [and] realistic, affordable and deliverable" (DCMS, 2009, pp. 1, 8, 2013, p. 6, inset added). Similarly, the guidance for 2017 stated: "What matters will not be the quantity of new proposals, initiatives and plans, or the size, glitz and glamour of the bids, but the quality of the thinking behind them, the level of ambition" (DCMS, 2013, p. 3).

We argue there is a tension between being 'reasonable and credible' and delivering 'demonstrable impact' in order to 'maximise legacy'. Given the conditioning forces of neoliberal urbanism, i.e. 'place wars' and the pressure to out-bid a competitor city, we suggest applicants are far more inclined to focus on the latter requirements than the former, hence the existence of impact inflation. We do not see this as clumsy economics or ignorance of reality. Rather it as a deliberate attempt to out-hype a rival area that is driven by the need to attract a high profile cultural event with anticipated benefits to the local economy and resident population. Another issue is the heavily circumscribed assessment criteria contained in the guidelines. This means that Central Government, via DCMS, has tight control over what they are actually assessing, and more importantly bidders are guided to make statements and claims on, for example, cultural engagement, economic outputs and social outcomes (DCMS, 2009, Appendix 1). We see this as another conditioning effect of neoliberal 'place wars'.

According to DCMS (2009, p. 2) "the bidding process has been designed to ensure that the best possible bid from across the UK is selected for UK City of Culture 2013”. Drawing upon workshops with candidate cities Wilson and O'Brien (2012) connect to our contention that neoliberal place competition is a significant factor in the bidding process. In explaining what motivated a city to apply for CoC Vickery identifies "a strong economic argument made by policy makers about the importance of cultural titles...for the local...economy" (quoted in Wilson \& O’Brien, 2012, p. 35). Similarly, Mould speaks of "a clear economic and regenerative motivation underpinning the cultural city mandate and the bidding process" (quoted in Wilson \& O’Brien, 2012, p. 39). In relation to the conditioning effect of neoliberal place competition Wilson and O’Brien (2012, p. 18) argue:

"The perceived focus on economic impact and regeneration created a certain tension between 'external' versus 'internal' requirements - cities felt challenged by what they really wanted out of 
the title and what was expected from them...the bid document felt technically constraining, and that ideas were being shoe-horned into particular agendas".

Linking to our concept of culturephilia, Campbel1 ${ }^{14}$ asserts how:

"[G]rand claims are nevertheless often made...regarding the potentially transformative nature of cultural engagement. This over-optimism may arise at least in part from the fact that it is often assumed within the discourse around programmes such as the UK CoC that cultural practice of any kind is a universal good" (quoted in Wilson \& O’Brien, 2012, p. 41).

\section{$D \sim L:$ bid, impact and legacy}

The island of Ireland was subjected to several centuries of British colonialism involving a sustained period of Scottish and English 'settler plantation' in $16^{\text {th }}$ and the $17^{\text {th }}$ Centuries. Fast forward to the early $20^{\text {th }}$ Century and the 'Irish question' was addressed through partition. In 1921 the island was physically separated between the twenty six counties of an independent Republic of Ireland and six north eastern counties who remained tied British rule, as part of the United Kingdom of Great Britain and Northern Ireland. Partition meant Northern Ireland was divided along religious, cultural and identity lines (Aughey, 2005). To this day one community (48\%) identify as religiously Protestant, culturally British and politically Unionist or Loyalist, the other (45\%) as Catholic, Irish and Nationalist or Republican (NISRA, 2014). Such divergent perceptions of identity and sovereignty provided the ammunition for 'the Troubles ${ }^{15}$ as ethno-sectarian warfare raged between Republicans ${ }^{16}$ battling for a united Ireland and Loyalists ${ }^{17}$ fighting to preserve the integrity of the Union. Covering three decades (1968-1998) the conflict cost over 3,600 people their lives. Despite the trauma of 'the Troubles', D L suffered 227 fatalities and became heavily segregated in terms of housing, education, consumption and lifestyle, the city continued to display a rich cultural heritage and so "for those preparing the bid D $\sim \mathrm{L}$ had a legitimate case to host UK CoC" (Boland et al., 2016, p. 5; also Doak, 2018).

$\mathrm{D} \sim \mathrm{L}$ is Northern Ireland's second largest city with a population of 109,150 but is very different to Belfast in that it is overwhelmingly Catholic $(74.83 \%)$ with a smaller Protestant $(22.34 \%)$ minority (NISRA,

\footnotetext{
${ }^{14}$ Vickery, Mould and Campbell provide commentaries in the report by Wilson and O'Brien.

15 'The Troubles' began in D L following the rise of the Civil Rights Movement in the late 1960s (Byrne, 2015).

16 The Irish Republican Army (IRA, of which there have been many incarnations), and the Irish National Liberation Army (INLA)

${ }^{17}$ The Ulster Defence Association (UDA), Ulster Volunteer Force (UVF) and Loyalist Volunteer Force (LVF).
} 
2014). To be selected as the inaugural UK CoC was regarded as a huge opportunity, and sense of pride, for $\mathrm{D} \sim \mathrm{L}$ as it emerged from the brutality of the conflict coupled with severe socio-economic problems; e.g. highest incidence of unemployment in the UK, haemorrhaging of young people (Boland et al., 2016, 2018; Doak, 2014, 2018; Gordon-Nesbitt, 2013; McDermott, Nic Craith \& Strani, 2016). Notwithstanding these labour market realities the bid document claimed $\mathrm{CoC}$ would be 'life and place changing' as it would stimulate economic growth, create jobs, improve life chances and enhance good relations (Derry City Council, 2010, pp. 2, 11, 14, 16). Reflecting the curing qualities of culture it is very noticeable that local elites interpreted culture as an 'economic resource' and 'peace resource' - "culture as a means to overcome division" (Nolan, 2014, p. 12). Interestingly for us, "during the 1970s, 80s and 90s cultural antagonisms were the cause of the conflict, whereas in 2013 cultural expression was perceived as curative" (Authors, 2016, p. 6). Official data alleges that during 2013 there were 400 events, 1.4 million visitors from 75 countries, $£, 100$ million global media reach and $f^{97.1}$ million economic impact ${ }^{18}$ (Derry City and Strabane District Council, 2016; Ilex, 2014). Moreover, the long-term targets for 2020 are f,98 million in additional wages and profits, 2800 net additional workplace jobs and 25\% growth in creative industries (Derry City Council, 2010, 2013b).

Clearly the bid and legacy documents anticipated that $\mathrm{CoC}$ would generate a 'similar transformative impact' as ECoC had in Liverpool and Glasgow and, very importantly, it was written during a period of relative optimism regarding the future trajectory of the global, national and local economies (Derry City Council, 2010). Connecting to culturephilia and the curing qualities of culture a senior official in the Culture Company told us:

"So culture was genuinely seen as a tool that could lead through tourism in terms of economic development, it was seen as a tool in terms of cultural and social development, and it was that glue. Excuse that pun but it really was seen as trying to bring the city and the whole city together" (Interview, 2016).

In understanding the context to and content of the bid document a number of our respondents referred to the role played by Oxford Economics ${ }^{19}$ in producing econometric modelling of the local economy, and the One Plan in providing the long-term strategic vision for the city. It is noticeable that the One

\footnotetext{
18 As in other cities of culture it is not entirely clear how these final calculations are justified (on Liverpool see Boland, 2010, 2013).

19 An independent advisory firms providing economic forecasting and modelling to private companies and financial institutions (www.oxfordeconomics.com/about/us).
} 
Plan contains 'very ambitious' projects aimed at securing the city's social, economic and physical redevelopment (Ilex, 2010). It is therefore reasonable to presume there is an extant tendency to elevate expectations that is not specific to $\mathrm{CoC}$; rather it is part of a wider neoliberal regeneration agenda reflective of the contemporary city (Lovering, 2007). A high ranking Council official intimated how the ambitious targets in the $\mathrm{CoC}$ bid document were derivative from the One Plan:

"So the One Plan was developed by Council and Ilex in terms of trying to get a 10 year community plan for the city that was going to address the social, economic and physical challenges in the city. There are a whole range of projects within that that are very ambitious... So the city's ambition was to use the CoC as a device in terms of fast-tracking some of the economic and social ambitions of the plan" (Interview, 2016).

As noted earlier it was interesting to hear a senior cultural policy officer within the Council speak about the advice they received during the bidding process. This is evidence of the incentive to inflate whereby expert assessors explicitly encouraged those responsible for producing the bid document to elevate expectations on 'effect' in order to out-bid rival cities - connecting to the dynamics of neoliberal 'place wars' outlined in our theoretical framework. The respondent explained: "Regeneris kept saying, who was the sort of oversight company, you have to prove that it means more to you than it does to anybody else. You have to prove that it will have a catalytic effect on your city, more than it does in any other place" (Interview, 2016). We do not see this as elite stakeholders engaging in 'phony/bad economics' (after Belfiore, 2009, 2015); in contradistinction, it shows they were consciously following instructions to inflate impact from expert assessors in the decision making process. In our view this reflects the nature of neoliberal place competition for a highly sought after cultural prize.

Given this, it is unsurprising that recent reports on the legacy of $\mathrm{CoC}$ acknowledge the bid document contained 'ambitious targets' on investment, jobs, tourism and education (Derry City Council, 2013a, b; Derry City and Strabane District Council, 2016; Ilex, 2014). One commentator is critical of the bid document. Gordon-Nesbitt (2013, p. 30) declares "those involved in the production of the City of Culture bid and the One Plan confess to having little hope that any of the targets will be reached". However, it is not clear from her paper exactly who the 'confessors' were (even with the cover of anonymity there are no verbatim quotes), or where the supporting evidence is (apart from a two line reference to a disused railway line); nor has care been taken to reflect on the allegation that contributors lacked confidence that 'any targets' would be met. To us, it seems inconceivable that professional people (we assume the reference to 'those' is plural) would be so casually confessional; in our view it is perfectly plausible that 
some contributors may well have had some reservations about some targets but to be as extensive in their lack of faith is highly questionable. This was confirmed by an experienced economist who was involved in the One Plan and $\mathrm{CoC}$ bid processes. Having previously read Gordon-Nesbitt's article he offered this response:

"Nobody to my knowledge involved in developing the bid would have been of this mindset. It is worth remembering that this was the first UK City of Culture and as such the parameters of the year were unknown. In effect, 'we didn't know any better' so any belief that we would not reach the targets would be based on what?" (Interview, 2016).

Interestingly, a small minority of non-elite stakeholder representatives fell into this accusatory category. For example, during a difficult on-the-record interview Willy Kelly of the Bogside Artists ${ }^{20}$ lambasted CoC: "It's all bullshit. We are more divided than before. It's all fantasy" (Interview, 2014). Obviously he was not using the word in question in precisely the same way as Belfiore (2009); however, the quote nevertheless captures an angry reaction to a perception of normality that is divorced from the official narrative of 2013. Firstly, we do not share his view that the narrative of CoC is 'bullshit/fantasy'; rather, the overwhelming evidence from our work (Authors, 2016, 2018) and the Post Project Evaluation (Derry City and Strabane District Council, 2016) is that positive cross-community relations occurred prior to, during and post $\mathrm{CoC}$ while significant civic pride at hosting such a prestigious event helped replace the historical negativity of a 'second city syndrome', and enhanced the image of the city internally and externally - thereby satisfying a key objective of DCMS (2013). Surprisingly for us, Doak (2018) is less convinced by the evidence of conflict transformation. Secondly, it is formally accepted that targets for investment and employment have been 'less successful/limited'. However, the (maybe fanciful) anticipation is that these, and other, economic benefits "may flow in the longer term from improved perceptions of the city and increased tourism" (Derry City and Strabane District Council, 2016, p. 43; also Ilex, 2014). In mitigation, an ongoing and deepening recession negatively affected the flow of public and private capital into the city thereby undermining serious progress on the anticipated economic outputs. This is evidence of the vagaries and volatilities of neoliberal globalisation. The economist explained:

\footnotetext{
${ }^{20}$ Three local artists who are responsible for painting the famous People's Gallery murals in the Bogside housing estate in $\mathrm{D} \sim \mathrm{L}$ (www.bogsideartists.com).
} 
"The 'failure' to reach the targets is primarily driven by two things. One, the budget allocated to the year was significantly less than that asked for/planned for. Two, the external economic context was completely different from that envisaged within the econometric planning model. Nobody forecast that the recession would be so deep and last for so long. Generally speaking the cyclical nature of the economy would have seen an upturn beginning in 2013" (Interview, 2016).

During an interview with a senior politician and former mayor of the city, who was an influential player in the application process to become $\mathrm{UK} \mathrm{CoC}$, we asked him to reflect on the need to deliver on economic targets, and the expectant claims of the bid and legacy documents. Reflecting on putting a bid together in a (neoliberal) competitive environment and the need to engage in impact inflation he explained: "Yeah I think they were overplayed at times. We should never, maybe we overdid it, but we should never pretend that it was ever meant to be the cure of all our ills" (Interview, 2014). Another local politician echoed the realisation that $\mathrm{CoC}$ was not intended as some magic bullet for the city's long-standing and deep-seated problems; instead, the bid document was primarily about securing the title and that some of the subsequent issues about lack of jobs emanated from the need to inflate targets during the application process. Equally importantly, and reinforcing the point made above, those producing the document and managing the process were cognisant that $\mathrm{CoC}$ was not going to be totally transformative. He informed:

"CoC was kind of teed up and people talked about it. Yes, it was going to be an amazing opportunity and it has been, but there was no way from the start that it was ever going to be a solution to all our problems...And you almost got that sense with some people, that it had been, oh what about those thousands of jobs this thing promised, and it was going to deliver this that and the other and bring the city together. The CoC alone was not going to solve all the issues that Derry had to face" (Interview, 2016).

Furthermore, a senior Council official stated that the hard-line economic focus of cities of culture can miss the truer softer side of impact and legacy (also Boland et al., 2016):

"I was talking about it in our board meeting yesterday. There's so much effort being placed, from Ilex and others, on the economic benefits, and the tourism visits, and you know the number of bed nights, and the number of businesses generated, all that sort of stuff. I think the bigger picture of what happened here over the last three years in particular, and throughout the CoC year, for me is the good relations. It is the difference it has made in the city" (Interview, 2016). 
On the issue of employment, respondents emphasised the much anticipated jobs in construction work failed to materialise due to the recession and this had a negative effect on the impact of CoC. Once again this emerges from debilitating economic circumstance. A third Ilex respondent explained:

"The modelling from Oxford Economics basically says that there'll be a lot of construction jobs in 2012. People miss that. Those jobs were expected to be gone by the end of 2012 - your construction will be complete, your hotels will be complete, the refurbishment, temporary accommodation will all be done... One thing we've been looking at is the differing composition between what was expected in the terms of the bid, and what actually occurred in terms of the spend. We had expected a lot more construction impacts, which would have set up capacity to enable the benefits to the city to be maximised. For a whole lot of reasons - as I said, the private sector had promised various bits and pieces a lot of that doesn't seem to have happened. That has constrained to some degree the economic impact this year" (Interview, 2016).

The vexed question of employment is the most tangible dimension of impact and legacy that ordinary people relate and react to. McDermott et al. (2016, p. 622) found "disappointment among some sections of the population of the inability of $\mathrm{CoC}$ to immediately increase employment rates". This inability to generate sufficient or sustainable jobs - only 300-400 jobs were actually created - is recognised in official reports (Derry City and Strabane District Council, 2016; Ilex, 2014). Confirming the findings of McDermott et al. (2016) our own research (Boland et al., 2016) discovered a distinct sense of frustration, apathy and cynicism amongst residents in poor working class (Catholic-Nationalist and ProtestantUnionist) housing estates. Our focus group conversations, capturing a range of demographics, revealed a deep dissatisfaction that decently paid permanent jobs had not been created prior to, during or after 2013, especially for young people (Boland et al., 2018). For many respondents CoC was an event primarily geared for affluent tourists and salaried classes. The key issue is not whether this is true, in several respects such a position can be disputed; however, it is the sense of detachment that people have towards CoC that is disturbing. This respondent epitomised the general consensus amongst our focus group attendees:

"It's like a depression. To come back to the legacy, it's a depression, because we had One Big Weekend, a massive event, once that left and everybody went. The Fleadh came, everybody was buzzing for eight days, then once that went away, them pop up bars shut down, some of the 
young people that worked in the pop up bars had no other jobs, and it's just back to reality then" (Interview, 2015).

\section{Conclusions}

This paper has analysed the impact and legacy of a major cultural event. The first point to make is the evidence presented here and elsewhere (Boland et al., 2016; Derry City and Strabane District Council, 2016) shows D L met the objectives for CoC set out by DCMS (2009, 2013). There was significant regional, national and international media interest in the city; there was a significant uplift in tourism during 2013; community relations have been significantly improved; and there was significant professional collaboration on cultural and creative projects. Notwithstanding this, we have also shown that, as in other cities, the economic legacy of $\mathrm{D} \sim \mathrm{L}$ is questionable due to extravagant and excessive targets that were placed into the bid document and legacy plans. We have shown that in the $\mathrm{D} \sim \mathrm{L}$ case elite stakeholders who produced the bid to become UK CoC followed the guidance of DCMS and clear instructions of expert assessors. The reality is that bidding for major cultural events necessarily involves elevated expectations regarding socio-economic transformation of the host city. This raises an important epistemological question: how do we understand this propensity to exaggerate? Our contribution to knowledge is that instructive insights can be garnered from framing the analysis within the theoretical lens of neoliberal urbanism, plus our own conceptual contribution centred on the three Cs, culturephilia and impact inflation. We do not claim that human agency is non-existent; however, we do contend that the intense pressures to host cultural events, i.e. neoliberal 'place wars', does significantly condition the actions and articulations of those producing the bid documentation resulting in impact inflation. It is clear that elite stakeholders are fully aware of the realities of their local economies, and that what they are presenting in terms of socio-economic transformation can be overstated. More broadly, bidding cities and judging panels realise the dynamics of competing for major cultural events necessarily involves hyperbole, and that it is essential in these neoliberal beauty contests to out-hype in order to out-bid and out-compete rival cities.

We end with a discussion of some lessons for other cities. The first point to make is that because neoliberal urbanism is extremely durable (Boland, Brontë \& Muir, 2017) intensified 'place wars' for cultural events are not going to disappear, so the conditioning effect of impact inflation will continue. We can debate the merits of excessive impact and legacy targets. However, the real issue is surely how the inability to achieve said targets affects ordinary working class people who logically interpret cultural events as delivering economic benefits, primarily much needed employment; when this fails to materialise 
despair and disillusionment set in. Going forward, our advice to local stakeholders applying to host future cities of culture is, notwithstanding the incentive to inflate, they must be fully cognisant of the consequences of not delivering on extravagant targets for those most marginalised in society. Raising disadvantaged people's hopes then dashing them with equal force is debilitating and destructive; without decent employment prospects then $\mathrm{CoC}$ is open for criticism that it merely caters for salaried elites with 'the politics of bread and circuses' (after Eisinger, 2000) for those at the margins. The danger is such residents continue to feel left out, and to a large extent ignored, by showcase cultural events that simply do not deliver for them as had been promised in the bidding process. Returning to the heart of the theoretical debate, this is where active human agency can help to militate and then mitigate the negative consequences that emerge during major cultural events. There needs to be a transparent and honest dialogue, between event deliverers and local people, so that expectations are tempered with some grounding in reality regarding what is genuinely achievable within specific timeframes. This would go some way to alleviating the levels of apathy and cynicism that emerge during and after a major cultural event.

\section{References}

Aalbers, M. (2013) ‘Neoliberalism is Dead ... Long Live Neoliberalism'. International Journal of Urban and Regional Research, 37(3): 1083-1090.

Allmendinger, P. \& Haughton, G. (2009) 'Soft spaces, fuzzy boundaries, and metagovernance: the new spatial planning in the Thames Gateway'. Environment and Planning A, 41(3): 617-633.

Allmendinger, P. \& Haughton, G. (2010) 'Spatial planning, devolution, and new planning spaces'. Environment and Planning C, 28(5): 803-818.

Allmendinger, P. \& Haughton, G. (2012) 'Post-political Spatial Planning in England: A Crisis of Consensus?' Transactions of the Institute of British Geographers, 37(1): 89-103.

Allmendinger, P. \& Haughton, G. (2013) 'The Evolution and Trajectories of Neoliberal Spatial Governance: 'neoliberal' episodes in planning'. Planning, Practice and Research, 28(1): 6-26.

Allmendinger, P. \& Haughton, G. (2015) 'Post-political regimes in English planning: from Third Way to Big Society’. In Metzger, J., Allmendinger, P. \& Oosterlynck, S. (Eds.) Planning Against the Political, London: Routledge, 29-54.

Amin, A. \& Thrift, N. (2007) 'Cultural-economy and cities'. Progress in Human Geography, 31(2): 143-161.

Ampuja M. (2015) ‘Globalisation and Neoliberalism: A New Theory for New Times?’ In Zajda, J. (Ed.) Second International Handbook on Globalisation, Education and Policy Research, 17-31. 
Ashworth, G. \& Kavaratzis, M. (2016) 'Cities of Culture and Culture in Cities: The Emerging Uses of Culture in City Branding'. In Haas, T. and Olsson, K. (Eds.) Emergent Urbanism: Urban Planning and Design in Times of Structural and Systemic Change, London: Routledge, pp. 73-79.

Aughey, A. (2005) The Politics of Northern Ireland: Beyond the Peace Agreement. London: Routledge.

Belfiore, E. (2006) 'The social impacts of the arts - myth or reality'. In Mirza, M. (Ed.) Culture Vultures: is UK arts policy damaging the arts? London: Policy Exchange Limited, pp. 20-37.

Belfiore, E. (2009) 'On bullshit in cultural policy practice and research: notes from the British case'. International Journal of Cultural Policy, 15(3): 343-359.

Belfiore, E. (2015) 'Impact', 'value' and 'bad economics': Making sense of the problem of value in the arts and humanities'. Arts and Humanities in Higher Education 14(1): 95-110.

Beveridge, R. \& Koch, P. (2017) 'The post-political trap? Reflections on politics, agency and the city'. Urban Studies, 54(1): 31-43.

Boland, P. (2010) “"Capital of Culture - you must be having a laugh!” Challenging the official rhetoric of Liverpool as the 2008 European Cultural Capital'. Social and Cultural Geography, 11(7): 627646.

Boland, P. (2013) 'Sexing up the city in the international beauty contest: the performative nature of spatial planning and the fictive spectacle of place branding'. Town Planning Review, 82(2): 251-274.

Boland, P., Brontë, J. \& Muir, J. (2017) 'On the Waterfront: the politics of public benefit in an era of neoliberal urbanism'. Cities, 61: 117-128.

Boland, P., Murtagh, B. \& Shirlow, P. (2016) 'Fashioning a city of culture: 'life and place changing' or '12 month party'?' International Journal of Cultural Policy: http://dx.doi.org/10.1080/10286632.2016.1231181

Boland, P., Mullan, L. \& Murtagh, B. (2018) 'Young people in a city of culture: 'ultimate beneficiaries' or 'economic migrants'?' Journal of Youth Studies, 21(2); 178-202.

Brenner, N. \& Schmid, C. (2015) 'Towards a new epistemology of the urban?' City, 19(2-3): 151-182.

Brenner, N. \& Theodore, N. (2002) 'Cities and the Geographies of “Actually Existing Neoliberalism”". Antipode, 34(3): 349-379.

Brenner, N. \& Theodore, N. (2005) 'Neoliberalism and the urban condition'. City, 9(1): 101-107.

Brenner, N., Peck, J. and Theodore, N. (2010) 'After Neoliberalism'. Globalizations, 7(3): 327-345. 
Brenner, N., Peck, J. \& Theodore, N. (2012) 'Towards Deep Neoliberalization'. In Künkel, J. \& Mayer, M. (Eds.) Neoliberal Urbanism and its Discontents. London: Palgrave Publisher, pp. 27-45. British Council (2012) The Power of Culture to Change Lives. London: British Council.

British Council (2014) Culture Matters. London: British Council.

Bryman, S. (2012) Social Research Methods. Oxford: Oxford University Press.

Byrne, M. (2015) 'Politics beyond Identity: Reconsidering the Civil Rights Movement in Northern Ireland'. Identities, 22(4): 468-485.

Castree, N. (2004) 'Economy and culture are dead! Long live economy and culture!' Progress in Human Geography, 28(2): 204-26.

Castree, N. (2010) 'Crisis, Continuity and Change: Neoliberalism, the Left and the Future of Capitalism'. Antipode, 41(/1): 185-213.

Chun, C. (2017) 'The dominant and everyday discourses of neoliberalism and globalization'. In Flowerdew, J. \& Richardson, J. (Eds.) The Routledge Handbook of Critical Discourse Studies: accessed via Google Scholar.

Colomb, C. (2011) 'Culture in the city, culture for the city? The political construction of the trickle-down in cultural regeneration strategies in Roubaix, France'. Town Planning Review, 82(1): 77-98.

Davidson, M. \& Iveson, K. (2015) 'Beyond city limits. A conceptual and political defense of 'the city' as an anchoring concept for critical urban theory'. City, 19(5): 646-664.

Department for Culture, Media and Sport (2009) UK City of Culture 2013: Bidding Guidance. London: DCMS.

Department for Culture, Media and Sport (2013) UK City of Culture 2017. Guidance for Bidding Cities. London: DCMS.

Department for Culture, Media and Sport (2015) Policy paper. 2010 to 2015 government policy: arts and culture. London: DCMS.

Derry City Council (2010) Cracking the Code. City of Culture 2013. Derry: Derry City Council.

Derry City Council (2013a) Our Legacy Promise. Building on the Success of 2013. Derry: Derry City Council.

Derry City Council (2013b) Legacy Plan 2013-2023. Derry: Derry City Council.

Derry City and Strabane District Council (2016) Post Project Evaluation of City of Culture 2013. Derry: Derry City and Strabane Council.

Dikeç, M. \& Swyngedouw, E. (2017) 'Theorizing The Politicizing City'. International Journal of Urban and Regional Research: DOI:10.1111/1468-2427.12388 
Doak, P. (2014) 'Beyond Derry or Londonderry: Towards a Framework for Understanding the Emerging Spatial Contradictions of Derry-Londonderry - UK City of Culture 2013'. City, 18 (4-5): 488-496.

Doak, P. (2018) 'Cultural policy as conflict transformation? Problematising the peacebuilding potential of cultural policy in Derry-Londonderry - UK City of Culture 2013'. International Journal of Cultural Policy, DOI: 10.1080/10286632.2018.1445727

Eisinger, P. (2000) 'The politics of bread and circuses. Building the city for the visitor class'. Urban Affairs Review, 35: 316-333.

European Commission (2014) European Capitals of Culture 2020-2033. Guide for Cities Preparing a Bid. Brussels: European Commission.

Evans, G. (2001) Cultural Planning: an urban renaissance. London: Routledge.

Falk, M. \& Hagsten, E. (2017) 'Measuring the impact of the European Capital of Culture programme on overnight stays: evidence for the last two decades'. European Planning Studies, 25(12): 21752191.

Featherstone, D. (2015) 'Thinking the crisis politically: lineages of resistance to neo-liberalism and the politics of the present conjuncture'. Space and Polity, 191(1): 12-30.

Featherstone, D., Strauss, K. \& MacKinnon, D. (2015) 'In, against and beyond neo-liberalism: The “crisis" and alternative political futures'. Space and Polity, 191(1): 1-11.

Ferguson, J. (2010) 'The Uses of Neoliberalism'. Antipode, 41(/1): 166-184.

Florida, R. (2003) 'Cities and the Creative Class'. City and Community, 2(1): pp. 3-19.

Garcia, B. \& Cox, T. (2013) European Capitals of Culture: Success Strategies and Long-Term Effects. Strasbourg: European Parliament.

Garcia, B. (2017) “If everyone says so...' Press narratives and image change in major event host cities’. Urban Studies, 54(14): 3178-3198.

Garnham, N. (2005) 'F rom cultural to creative industries. An analysis of the implications of the "creative industries" approach to arts and media policy making in the United Kingdom'. International Journal of Cultural Policy, 11(1): 15-29.

Gattinger, M. \& Saint-Pierre, D. (2010) "The "Neoliberal Turn" in Provincial Cultural Policy Administration in Québec and Ontario: The Emergence of 'Quasi-Neoliberal Approaches". Canadian Journal of Communication, 35(2): 279-302.

Gibson, L. \& Stevenson, D. (2004) 'Urban space and the uses of culture'. International Journal of Cultural Policy, 10(1): 1-4.

Gordon-Nesbitt, R. (2013) 'Misguided Loyalties'. Conflict, Community, Culture. Derry. 
Gold, J. \& Gold, M. (2008) 'Olympic cities: regeneration, city rebranding and changing urban agendas'. Geography Compass, 2(1): 300-318.

Gray C. (2006) 'Managing the Unmanageable: the Politics of Cultural Planning', Public Policy and Administration, 21(2): 101-113.

Gunay, Z. (2010) 'Conservation versus Regeneration? Case of European Capital of Culture 2010 Istanbul'. European Planning Studies, 18(8): 1173-1186.

Hall, S. (2011) 'The Neo-Liberal Revolution'. Cultural Studies, 25(6): 705-728.

Harvey, D. (1989) 'From Managerialism to Entrepreneurialism: The Transformation in Urban Governance in Late Capitalism'. Geografiska Annaler. Series B, Human Geography, 71(1): $3-17$.

Harvey, D. (2006) 'Neoliberalism as creative destruction'. Geografiska Annaler: Series B, Human Geography, 88(2): 145-158.

Haughton, G., Allmendinger, P. \& Oosterlynck, S. (2013) 'Space of neoliberal experimentation: soft spaces, postpolitics, and neoliberal governmentality'. Environment and Planning A, 45(1): 217234.

Hay, C. (2011) 'Interpreting Interpretivism Interpreting Interpretations: The New Hermeneutics of Public Administration'. Public Administration, 89(1): 167-182.

Hesmondhalgh, D., Nisbett, M., Oakley, K. \& Lee, D. (2015) ‘Were New Labour’s cultural policies neoliberal?' International Journal of Cultural Policy, 21(1): 97-114.

Ilex (2014) Second Monitoring Report: City of Culture 2013. Derry: Ilex.

Jessop, B. (2002) 'Liberalism, Neoliberalism, and Urban Governance: A State-Theoretical Perspective'. Antipode, 34(3): 452-472.

Jessop, B. (2013) 'Putting neoliberalism in its time and place: a response to the debate'. Social Anthropology, 21(1): 65-74.

Kavaratzis, M. and Ashworth, G. (2015) 'Hijacking culture: the disconnection between place culture and place brands'. Town Planning Review, 86(2): 155-176.

Keil, R. (2009) `The urban politics of roll-with-it neoliberalization’. City, 13(2-3): 230-245.

Lähdesmäki, T. (2013) 'Cultural activism as a counter-discourse to the European Capital of Culture programme: The case of Turku 2011'. European Journal of Cultural Studies, 16(5): 598-619.

Lähdesmäki, T. (2014) 'European Capital of Culture Designation as an Initiator of Urban Transformation in the Post-Socialist Countries'. European Planning Studies, 22(3): 481-497.

Landry, C. (2006) Lineages of the Creative City. Accessed on $16^{\text {th }}$ July 2007 via: www.comedia.org.uk/pages/pdf/downloads/Lineages of the Creative City.pdf 
Landry, C. \& Wood, P. (2003) Harnessing and exploiting the power of culture for competitive advantage. A Report for Liverpool City Council and the Core Cities. Accessed on $14^{\text {th }}$ May 2015 via: www.culturenet.cz/res/data/004/000569.pdf

Le Galès, P. (2016) 'Neoliberalism and Urban Change: Stretching a Good Idea Too Far?' Territory, Politics, Governance, 4(2): 154-172.

Lovering, J. (2007) 'The relationship between urban regeneration and neoliberalism: two presumptuous theories and a research agenda'. International Planning Studies, 12(4): 343-366.

MacLeod, G. \& Jones, M. (2011) ‘Renewing urban politics’ Urban Studies, 48(12): 2443-2472.

Markusen, A. \& Gadwa, A. (2010) 'Arts and Culture in Urban or Regional Planning: A Review and Research Agenda'. Journal of Planning Education and Research, 29(3): 379-391.

Massey, D. (2014) 'Symposium: The Kilburn Manifesto: after neoliberalism?' Environment and Planning A, 46(9): 2033-2049.

Mayer, M. \& Künkel, J. (2012) 'Introduction: Neoliberal Urbanism and its Contestations - Crossing Theoretical Boundaries'. In Künkel, J. and Mayer, M. (Eds.) Neoliberal Urbanism and its Contestations: Crossing Theoretical Boundaries. Basingstoke: Palgrave Macmillan, pp. 3-26.

McDermott, P., Nic Craith, M. \& Strani, K. (2016) 'Public Space, Collective Memory and Intercultural Dialogue in a (UK) City of Culture'. Identities, 23(5): 610-627.

McGuigan, J. (2005) 'Neo-Liberalism, Culture and Policy'. International Journal of Cultural Policy, 11(3): 229-241.

McGuigan, J. (2009) 'Doing a Florida thing: the creative class thesis and cultural policy'. International Journal of Cultural Policy, 15(3): 291-300.

McGuirk, P. (2005) 'Neoliberalist planning? Re-thinking and re-casting Sydney's metropolitan planning'. Geographical Research, 43(1): 59-70.

McGuirk, P. (2015) 'Geographical theorizing for a world of cities'. Progress in Human Geography, DOI: $10.1177 / 0309132515603838,1-7$.

Medway, D. \& Warnaby G. (2014) 'What's in a name? Place branding and toponymic commodification'.

Environment and Planning A, 46(1) 153-167.

Miles, S. (2005) 'Measure for measure: Evaluating the evidence of culture's contribution to regeneration'.

Urban Studies, 42(5-6): 959-983.

Miles, S. \& Paddison, R. (2005) 'Introduction: The Rise and Rise of Culture-Led Regeneration'. Urban Studies, 42(5-6): 833-839.

Miller, T. (2008) 'From creative to cultural industries. Not all industries are cultural, and no industries are creative'. Cultural Studies, 23(1): 88-99. 
Mooney, G. (2004) 'Cultural Policy as Urban Transformation? Critical Reflections on Glasgow, European City of Culture 1990'. Local Economy, 19(4): 327-340.

Morgan, K. (2014) 'Age of the City-Region'. Agenda: Journal of the Institute of Welsh Affairs, accessed via: www.iwa.wales/click/2014/03/putting-cardiff-and-the-valleys-on-the-maptogether/

Murtagh, B., Boland, P. \& Shirlow, P. (2017) 'Contested heritages and cultural tourism'. International Journal of Heritage Studies, 23(6): 506-520.

Németh, Á. (2016) 'European Capitals of Culture - Digging Deeper into the Governance of the Megaevent'. Territory, Politics, Governance, 4(1): 52-74.

Newman, J. (2014) 'Landscapes of Antagonism: Local Governance, Neoliberalism and Austerity'. Urban Studies, 51(15): 3290-3305.

Newsinger, J. (2105) 'A cultural shock doctrine? Austerity, the neoliberal state and the creative industries discourse'. Media, Culture and Society, 37(2): 302-313.

NISRA (Northern Ireland Statistics and Research Agency) (2014) Northern Ireland Local Government District Tourism Statistics Additional Tables 2014. Accessed May 2017 via: www.detini.gov.uk/publications/local-government-district-tourism-statistics-publications

Nutley, S., Davies, H. \& Walter, I. (2002) Evidence Based Policy and Practice: Cross Sector Lessons From the UK. ESRC Centre for Evidence Based Policy and Practice Working Paper 9. Research Unit for Research Utilisation, Department of Management, University of St Andrews.

O’Brien, D. (2011) 'Who is in charge? Liverpool, European Capital of Culture 2008 and the governance of cultural planning. Town Planning Review, 82(1): 45-59.

O'Callaghan, C. (2012) 'Urban anxieties and creative tensions in the European Capital of Culture 2005: 'It couldn't just be about Cork, like”. International Journal of Cultural Policy, 18(2): 185-204. O'Callaghan, C. \& Linehan, D. (2007) 'Identity, Politics and Conflict in Dockland Development in Cork, Ireland: European Capital of Culture 2005'. Cities, 24(4): 311-323.

Olesen, K. (2013) 'Soft spaces as vehicles for neoliberal transformations of strategic spatial planning'. Environment and Planning C, 30(5): 288-303.

Olesen, K. (2014) 'The neoliberalisation of strategic spatial planning'. Planning Theory, 13(3): 288-303. Ooi, C., Håkanson, L. \& LaCava, L. (2014) 'Poetics and Politics of the European Capital of Culture Project'. Procedia - Social and Behavioral Sciences, 148: 420-427.

Oosterlynck, S. \& Gonzalez, S. (2013) “Don't Waste a Crisis': Opening up the City Yet Again for Neoliberal Experimentation'. International Journal of Urban and Regional Research, 37(3): 1075-1082. 
Paddison, R. (2009) 'Some reflections on the limitations to public participation in the post-political city'. L'Espace Politique. Available at: https://espacepolitique.revues.org/1393\#toc

Peck, J. (2014) 'Entrepreneurial Urbanism: between uncommon sense and dull compulsion'. Geografiska Annaler: Series B, Human Geography, 96(4): 396-401.

Peck, J. (2015) 'Cities beyond Compare’. Regional Studies, 49(1): 160-182.

Peck, J. \& Tickell, A. (2002) 'Neoliberalizing space'. Antipode, 34(3): 380-404.

Peck, J. \& Tickell, A. (2006) ‘Conceptualizing neoliberalism, thinking Thatcherism’. In Leitner, H., Peck, J. \& Sheppard, E. (Eds.) Contesting neoliberalism: Urban frontiers. New York: The Guilford Press, pp. 26-50.

Peck, J., Brenner, N. \& Theodore, N. (2009) 'Neoliberal Urbanism: Models, Moments, Mutations'. SAIS Review, 29(1): 49-66.

Peck, J., Theodore, N. \& Brenner, N. (2010) 'Postneoliberalism and its malcontents'. Antipode, 41(/1): 95-116.

Peck, J., Theodore, N. \& Brenner, N. (2013) 'Neoliberal Urbanism Redux?’ International Journal of Urban and Regional Research, 37(3): 1091-1099.

Pike A. (2013) 'Economic Geographies of Brands and Branding'. Economic Geography, 89(4), 317339.

Pike A., Rodríguez-Pose, A. \& Tomaney, J. (2017) 'Shifting horizons in local and regional development'. Regional Studies, 51(1): 46-57.

Pinson, P. \& Morel Journel, C. (2016) 'The Neoliberal City - Theory, Evidence, Debates'. Territory, Politics, Governance, 4(2): 137-153.

Pratt, A. (2004) 'The cultural economy. A call for spatialised 'production of culture' perspectives'. International Journal of Cultural Studies, 7(1): 117-128.

Pratt, A. (2010) 'Creative cities: Tensions within and between social, cultural and economic development. A critical reading of the UK experience'. City, Culture and Society, 1(1): 13-20.

Pratt, A. (2011) 'The cultural contradictions of the creative city'. City, Culture and Society, 2(3): 123130.

Pratt, A. (2014) Cities: The cultural dimension. London: Foresight, Government Office for Science.

Richards, G. \& Wilson, J. (2004) 'The Impact of Cultural Events on City Image: Rotterdam, Cultural Capital of Europe 2001'. Urban Studies, 41(10): 1931-1951.

Sager, T. (2011) 'Neo-liberal urban planning policies: A literature survey 1990-2010'. Progress in Planning, 76(4): 147-199. 
Sager, T. (2015) 'Ideological traces in plans for compact cities: Is neo-liberalism hegemonic?' Planning Theory, 4(3): 268-295.

Sager, T. (2016) 'Activist planning: a response to the woes of neo-liberalism?' European Planning Studies, 24(7): 1262-1280.

Sheppard, E., Gidwini, V., Goldman, M., Leitner, H., Roy, A. \& Maringanti, A. (2015) 'Introduction: Urban revolutions in the age of global urbanism'. Urban Studies, 52(11): 1947-1961.

Sjøholt, P. (1999) 'Culture as a Strategic Development Device: The Role of 'European Cities of Culture, with Particular Reference to Bergen'. European Urban and Regional Studies, 6(4): 339-347.

Stevenson, D. (2004) “CIVIC GOLD” RUSH. Cultural planning and the politics of the Third Way'. International Journal of Cultural Policy, 10(1): 119-131.

Stevenson, D., Rowe, D. \& McKay, K. (2010) 'Convergence in British Cultural Policy: The Social, the Cultural, and the Economic'. Journal of Arts Management, Law and Society, 40(4): 248-264. Storper, M. (2016) 'The Neo-liberal City as Idea and Reality'. Territory, Politics, Governance, 4(2): 241 263.

Swyngedouw, E. (2017) 'Unlocking the mind-trap: Politicising urban theory and practice'. Urban Studies, 54(1): 55-61.

Taylor, C. (2006) 'Beyond advocacy: Developing an evidence base for regional creative industry strategies'. Cultural Trends, 15(1): pp. 3-18.

Tretter, E. (2009) 'The Cultures of Capitalism: Glasgow and the Monopoly of Culture'. Antipode, 41(1): 111-132.

Tucker, M. (2008) 'The cultural production of cities: Rhetoric or reality? Lessons from Glasgow'. Journal of Retail and Leisure Property, 7(1): 21-33.

United Nations Scientific and Cultural Organization (UNESCO)/United Nations Development Programme (UNDP) (2013) Creative Economy Report. Paris: UNESCO.

Warwick Commission (2015) Enriching Britain: Culture, Creativity and Growth. Coventry: University of Warwick.

Watkins, S. (2010) 'Shifting Sands'. New Left Review, 61: 5-27.

Wilson, K. \& O’Brien, D. (2012) It's Not the Winning...Reconsidering the Cultural City. A report on the Cultural Cities Research Network 2011-12. Project funded by Institute of Cultural Capital and Arts and Humanities Research Council.

World Cities Cultural Forum (2013) World Cities Cultural Report. London: World Cities Cultural Forum. 